\title{
Molecular Mapping of Stripe Rust Resistance Gene Yr76 in Winter Club Wheat Cultivar Tyee
}

\author{
C. Xiang, J. Y. Feng, M. N. Wang, X. M. Chen, D. R. See, A. M. Wan, and T. Wang
}

First and seventh authors: Chengdu Institute of Biology, Chinese Academy of Sciences, Chengdu, Sichuan 610041, China; first, second, third, fourth, fifth, and sixth authors: Department of Plant Pathology, Washington State University, Pullman 99164-6430; second author: Biotechnology and Nuclear Technology Research Institute, Sichuan Academy of Agricultural Sciences, Chengdu, Sichuan 610061, China; and fourth and fifth authors: U.S. Department Agriculture, Agricultural Research Service, Wheat Health, Genetics, and Quality Research Unit, Pullman, WA 99164-6430. Accepted for publication 26 March 2016.

\begin{abstract}
Xiang, C., Feng, J. Y., Wang, M. N., Chen, X. M., See, D. R., Wan, A. M., and Wang, T. 2016. Molecular mapping of stripe rust resistance gene $\operatorname{Yr} 76$ in winter club wheat cultivar Tyee. Phytopathology 106:1186-1193.

Tyee, one of the wheat cultivars used to differentiate races of Puccinia striiformis f. sp. tritici in the United States, was identified to have a single gene for all-stage resistance, tentatively named YrTye. To map the gene, Tyee was crossed with 'Avocet Susceptible' (AvS). Genetic analysis of the $\mathrm{F}_{1}, \mathrm{~F}_{2}, \mathrm{~F}_{2: 3}$, and $\mathrm{BC}_{1}$ progenies confirmed a single dominant gene for resistance to race PSTv-37 that is avirulent to YrTye. A mapping population of $135 \mathrm{~F}_{2}$ plants was phenotyped with PSTv-37 and the derived $\mathrm{F}_{2: 3}$ lines were tested with races PSTv-37, PSTv-40, and PSTv-79. The $\mathrm{F}_{2}$ mapping

3AS flanked distally by SSR marker wmc11 and proximally by wmc532 at 2.6 and $3.4 \mathrm{cM}$, respectively. Amplification of Chinese Spring 3A deletion lines placed the gene in the distal bin 3AS4-0.45 to 1.00 . Because YrTye is different from all formally named $Y r$ genes in chromosomal location, we permanently name the gene $\operatorname{Yr} 76$. A near-isogenic line of spring common wheat was developed and selected by testing $\mathrm{F}_{3}$ lines derived from a AvS*4/ Tyee cross with Tyee-avirulent and virulent races and the flanking markers. The specific SSR alleles flanking $Y r 76$ were validated using cultivars and breeding lines with and without the gene, and showed high polymorphisms. The specificity of $Y r 76$ is useful in differentiating P. striiformis f. sp. tritici races, and its tightly linked markers will be useful in developing resistant cultivars when combining the gene with other genes for resistance to stripe rust.
\end{abstract} population was genotyped with simple sequence repeat (SSR) markers. A genetic map comprising 13 SSR markers located YrTye in chromosome
Additional keywords: Triticum aestivum sp. compactum, yellow rust.
Stripe rust (yellow rust), caused by Puccinia striformis Westend. f. sp. tritici Erikss., is one of the most important and damaging diseases of wheat in all wheat production regions in the world (Chen 2005; Chen et al. 2014; Stubbs 1985; Wellings 2011). In the Pacific Northwest of the United States, where climatic conditions and cropping systems are favorable for stripe rust, the disease occurs every year. Based on experimental data from 1975 to 2012, stripe rust can cause yield losses on susceptible varieties ranging from $3 \%$ to more than $90 \%$, with a mean of $36 \%$ for winter wheat and 30\% for spring wheat (Chen 2014; Sharma-Poudyal and Chen 2011). Throughput the United States, severe epidemics of wheat stripe rust occurred in 2001, 2003, 2005, 2010, and 2012, causing yield losses estimated as 1.08, 2.42, 2.00, 2.61, and 1.49 million metric tons, respectively, even after millions of dollars were spent on fungicides to reduce the damage (Chen 2014; http:// striperust.wsu.edu).

Resistant cultivars are the most effective, economical, easy-touse, and environmentally friendly approach to control stripe rust (Chen 2013; Line and Chen 1995). Resistance to stripe rust is generally classified as two types, all-stage resistance (also called seedling resistance) and adult-plant resistance (Chen 2005, 2013).

Corresponding author: X. M. Chen; E-mail address: xianming@wsu.edu

First and second authors made equal contribution to this study.

*The $\boldsymbol{e}$-Xtra logo stands for "electronic extra" and indicates that one supplementary figure is published online.

http://dx.doi.org/10.1094/PHYTO-01-16-0045-FI

This article is in the public domain and not copyrightable. It may be freely reprinted with customary crediting of the source. The American Phytopathological Society, 2016.
Both types of resistance have advantages and disadvantages. Allstage resistance often provides high levels of protection, but is usually race-specific and not durable (Chen 2005; Chen and Line 1995; Johnson 1981). In contrast, adult-plant resistance, with some exceptions, is usually non-race-specific, but often provides partial protection that may be inadequate when the disease starts early, temperatures remain low, and inoculum loads are high (Chen 2005, 2013 , 2014). When the two types of resistance are combined, they can be complementary and provide high levels of protection as well as durability. To search for wheat germplasm for either type of resistance, it is important to differentiate $P$. striiformis $\mathrm{f}$. sp. tritici races using wheat lines with clearly characterized resistance genes and to use selected races to characterize new resistance sources and breeding lines for releasing new resistant cultivars.

'Tyee' (CItr 17773) is a soft white winter club wheat cultivar released by the U.S. Department of Agriculture-Agricultural Research Service (USDA-ARS) and Washington State University in 1979 (Allan et al. 1980). Before and when it was released, it was highly resistant to all U.S. P. striiformis $\mathrm{f}$. $\mathrm{sp}$. tritici races identified at that time. However, Tyee became susceptible and was added to the differential set in 1983 (Line and Qayoum 1992). Since then, 130 races avirulent and 25 races virulent to Tyee have been identified in the United States (Chen 2005; Chen et al. 2002, 2010; Line and Qayoum 1992; Wan and Chen 2012, 2014; Wan et al. 2016). Variation in the response of Tyee was also observed among $P$. striiformis f. sp. tritici isolates from Australia, Canada, Chile, China, Ecuador, Hungary, Italy, Kenia, Nepal, Turkey, and Uzbekistan (Sharma-Poudyal et al. 2013; Zhan et al. 2012; A. M. Wan and X. M. Chen, unpublished data).

In order to provide clearer information on races, Wan and Chen (2014) adopted a new set of differentials comprising 18 lines each with a single $Y r$ gene for stripe rust resistance. The set includes Tyee, the only winter wheat cultivar and not an established 
near-isogenic line. Using the new differential set, 53 races avirulent and 35 races virulent to Tyee were identified in the United States, and 43 races avirulent and 12 races virulent were identified among isolates from other countries since 2010 (Wan and Chen 2014; Wan et al. 2016; A. M. Wan and X. M. Chen, unpublished data). The races virulent on Tyee were predominant in the U.S. Pacific Northwest from the middle 1980s and the middle 1990s, disappeared until 2006, and new races virulent to Tyee emerged and became predominant from 2007 to 2012 (Chen 2005; Chen et al. 2010; Line and Qayoum 1992; Wan and Chen 2012, 2014; Wan et al. 2016). It is interesting that the $P$. striiformis f. sp. tritici population in the United States can be separated into two major groups based on virulence or avirulence to YrTye, and that the two

TABLE 1. Infection types on seedlings of Avocet Susceptible (AvS) and Tyee produced by races of Puccinia striiformis f. sp. tritici under controlled greenhouse conditions

\begin{tabular}{lcccc}
\hline & & \multicolumn{2}{c}{$\begin{array}{c}\text { Infection } \\
\text { type }\end{array}$} \\
\cline { 3 - 5 } Race $^{\mathrm{a}}$ & \multicolumn{2}{c}{ Virulence/avirulence formula on $Y r$ genes $^{\mathrm{b}}$} & AvS & Tyee \\
\hline PSTv-4 & $1,6,9,17,27, \mathrm{SP}, \mathrm{Tye} / 5,7,8,10,15,24,32,43,44, \operatorname{Tr} 1$, Exp2 & 8 & 8 \\
PSTv-11 & $1,6,7,8,9,17,27,43,44$, Exp2,Tye/5,10,15,24,32,SP,Tr1 & 8 & 8 \\
PSTv-14 & $1,6,7,8,9,17,27,43,44, \operatorname{Tr} 1$, Exp2,Tye/5,10,15,24,32,SP & 8 & 8 \\
PSTv-17 & $1,6,7,8,9,17,27,43,44$, SP,Exp2,Tye/5,10,15,24,32,Tr1 & 8 & 8 \\
PSTv-30 & $6,7,8,9,44, \operatorname{Tr} 1$, Exp2/1,5,10,15,17,27,24,32,43,SP,Tye & 8 & 2 \\
PSTv-34 & $6,7,8,9,17,27,44, \operatorname{Tr} 1$, Exp2/1,5,10,15,24,32,43,SP,Tye & 8 & 2 \\
PSTv-37 & $6,7,8,9,17,27,43,44, \operatorname{Tr} 1$, Exp2/1,5,10,15,24,32,SP,Tye & 8 & 2 \\
PSTv-40 & $6,7,8,9,10,24,27,32,43,44, \operatorname{Tr} 1$, Exp2/1,5,15,17,SP,Tye & 8 & 1 \\
PSTv-41 & $6,7,8,9,10,17,24,27,32,43,44, \operatorname{Tr} 1$, Exp2/1,5,15,SP,Tye & 8 & 2 \\
PSTv-51 & $1,6,7,8,9,10,17,24,27,32,43,44$, SP,Tr1,Exp2,Tye/5,15 & 8 & 8 \\
PSTv-55 & $1,6,7,17$, Exp2/5,8,9,10,15,24,27,32,43,44,SP,Tr1,Tye & 8 & 2 \\
PSTv-61 & $10,24,32, \operatorname{Tr} 1 / 1,5,6,7,8,9,15,17,27,43,44$, SP,Exp2,Tye & 8 & 2 \\
PSTv-79 & $1,7,9,44 / 5,6,8,10,15,17,24,27,32,43$, SP,Tr1,Exp2,Tye & 8 & 2 \\
\hline
\end{tabular}

a PSTv races were differentiated using a set of wheat $Y r$ single-gene lines as described in Wan and Chen (2014) and confirmed in the present study.

b The $18 Y r$ single-gene line differentials are listed in Wan and Chen (2014). major virulence groups correspond to two major genetic groups determined using molecular markers (Cheng and Chen 2014; Wan and Chen 2014; Wan et al. 2016). In general, the frequencies of virulence to Tyee were low in other countries compared with the United States (Sharma-Poudyal et al. 2013; Zhan et al. 2012; A. M. Wan and X. M. Chen, unpublished data).

Previous genetic studies have determined that Tyee has a single gene for resistance to stripe rust, temporarily named YrTye (Chen and Line 1992a, b; Chen et al. 1995). YrTye was tentatively located on chromosome 6D by monosomic analysis (Chen et al. 1995). However, the specific chromosomal region of YrTye was unknown, and there were no molecular markers available for the resistance gene. The objectives of this study were to map YrTye, determine its relationships with other stripe rust resistance genes, identify and validate markers closely linked to the gene, and develop a nearisogenic line for the gene in a spring common wheat background.

\section{MATERIALS AND METHODS}

Development of a mapping population and a near-isogenic line. To map YrTye, the winter club wheat Tyee was crossed with susceptible spring wheat genotype 'Avocet Susceptible' (AvS). Seedlings of Tyee and later $\mathrm{F}_{2}$ plants were vernalized in a growth chamber at $4^{\circ} \mathrm{C}$ for 4 to 5 weeks before growing in the greenhouse for selfing and crossing. $\mathrm{F}_{1}, \mathrm{~F}_{2}, \mathrm{~F}_{2: 3}, \mathrm{BC}_{1}$, and later generation progenies were generated either in a greenhouse or the field.

A near-isogenic line (NIL) $\mathrm{BC}_{3}: \mathrm{F}_{3}$ was developed by backcrossing to AvS. Resistant $\mathrm{BCF}_{1}$ plants were selected using race PSTv-37 which is avirulent on Tyee. Resistant $\mathrm{BC}_{3} \mathrm{~F}_{1}$ and $\mathrm{BC}_{3} \mathrm{~F}_{2}$ plants and $\mathrm{BC}_{3} \mathrm{~F}_{3}$ lines were selected by stripe rust tests and flanking markers.

Evaluation of stripe rust reactions. Seedling tests were conducted under controlled greenhouse conditions as previously described (Chen and Line 1992a, b). Thirteen P. striiformis f. sp. tritici races (PSTv-4, PSTv-11, PSTv-14, PSTv-17, PSTv-30, PSTv-34, PSTv-37, PSTv-40, PSTv-41, PSTv-51, PSTv-55, PSTv-61, and PSTv-79) were used to test the responses of Tyee and AvS. These

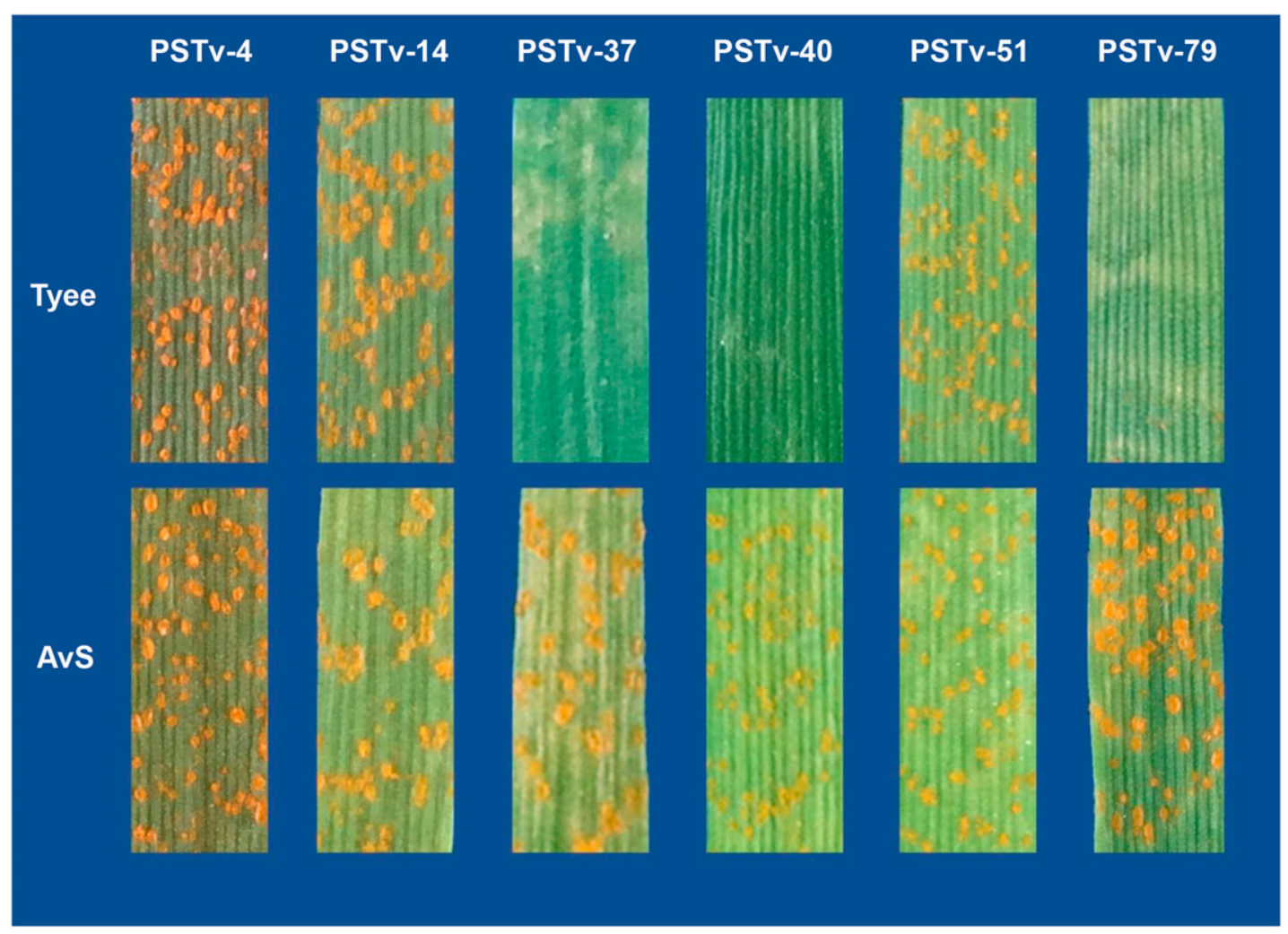

Fig. 1. Reactions of Tyee and Avocet Susceptible (AvS) to different races of Puccinia striiformis f. sp. tritici. 
races represented predominant races and/or various race groups (Wan and Chen 2014; Wan et al. 2016; A. M. Wan and X. M. Chen, unpublished data). PSTV-37, the most frequently identified race throughout the United States in the recent years, was used to test the $\mathrm{F}_{2}$ and $\mathrm{F}_{2: 3}$ populations derived from AvS $\times$ Tyee. The $\mathrm{F}_{2: 3}$ lines were also tested with PSTv-40 and PSTv-79, both also avirulent on Tyee. Urediniospores of each race were increased on AvS, and their identities were confirmed by testing on the 18 differentials following previously described procedures (Wan and Chen 2014).

Seedlings of parents and $F_{2}$ and $F_{2: 3}$ populations were grown in the greenhouse. About 15 seeds of each parent, 135 seeds $F_{2}$, and $135 \mathrm{~F}_{2: 3}$ lines each with about 15 seeds were planted in plastic pots $(6 \times 6 \times 6 \mathrm{~cm})$ filled with a potting medium ( 6 liters of peat moss, 2 liters of perlite, 3 liters of sand, 3 liters of potting soil mix, 4 liters of vermiculite, $300 \mathrm{ml}$ of Osmocote, and 2 liters of water). Inoculations were conducted at the two-leaf stage as described by Chen and Line (1992a, b). Inoculated seedlings were kept in a dew chamber at $10^{\circ} \mathrm{C}$ for $24 \mathrm{~h}$ without light, and then grown in a growth chamber operating at $16 \mathrm{~h}$ light and $8 \mathrm{~h}$ darkness with diurnal temperatures gradually

TABLE 2. Seedling reactions of parents, $F_{1}$ plants, $F_{2}$ population, $F_{2: 3}$ lines and $\mathrm{BC}_{1}$ plants from cross Avocet Susceptible $(\mathrm{AvS}) \times$ Tyee to Puccinia striiformis f. sp. tritici race PSTv-37

\begin{tabular}{lrccccc}
\hline & \multicolumn{3}{c}{ No. of observed plants or lines } & \multicolumn{2}{c}{ Expected ratio } \\
\cline { 2 - 4 } Generation & Resistant & Segregating & Susceptible & (Res: Seg: Sus) & $P$ \\
\hline AvS & 0 & - & 15 & - & - \\
Tyee & 15 & - & 0 & - & - \\
$\mathrm{F}_{1}$ & 5 & - & 0 & - & - \\
$\mathrm{F}_{2}$ & 103 & 0 & 32 & $3: 1$ & 0.73 \\
$\mathrm{~F}_{2: 3}{ }^{\mathrm{a}}$ & 34 & 69 & 32 & $1: 2: 1$ & 0.94 \\
$\mathrm{BC}_{1}$ & 19 & 0 & 18 & $1: 1$ & 0.87 \\
\hline
\end{tabular}

a The $\mathrm{F}_{2: 3}$ population tested with races PSTv-40 and PSTv-79 produced the same numbers of resistant, segregating, and susceptible lines as in the test with race PSTv-37. changing from $4{ }^{\circ} \mathrm{C}$ at 2:00 a.m. to $20^{\circ} \mathrm{C}$ at 2:00 p.m. Infection type (IT) data were recorded 18 to 21 days after inoculation based on the 0 to 9 scale described by Line and Qayoum (1992).

DNA extraction and SSR marker analysis. Genomic DNA was extracted from leaf tissue of each $\mathrm{F}_{2}$ plant and the parents using the method described by Riede and Anderson (1996). DNA was dissolved in TE buffer (10 mM Tris- $\mathrm{HCl}$ and $1 \mathrm{mM}$ EDTA, $\mathrm{pH}$ 8.0). DNA quality was determined using $0.8 \%$ agarose gel electrophoresis, and the DNA concentration was measured using a NanoDrop ND-1000 (Thermo Scientific, Wilmington, DE). The stock DNA solution was diluted to $25 \mathrm{ng} / \mu \mathrm{l}$ with sterile deionized distilled (dd) $\mathrm{H}_{2} \mathrm{O}$ for use as template in polymerase chain reaction (PCR).

TABLE 3. Amplicons of simple sequence repeat (SSR) markers flanking the YrTye locus in wheat genotype Tyee, Avocet Susceptible (AvS), Chinese Spring (CS), and 21 nulli-tetrasomic (NT), and nine deletions (Del) lines of CS

\begin{tabular}{lcc}
\hline & \multicolumn{2}{c}{ Amplicon of SSR marker (bp) } \\
\cline { 2 - 3 } Wheat genotype & wmc11 & $w m c 532$ \\
\hline Parents and CS & 200 & 178 \\
AvS & 204 & 182 \\
Tyee & 201 & 196 \\
CS & & \\
NT lines & Absent & Absent \\
N3AT3D & 201 & 196 \\
All other 20 NT lines & & \\
Deletion lines & Absent & Absent \\
Del 3AS-1 & Absent & Absent \\
Del 3AS-2 & Absent & Absent \\
Del 3AS-4 & 201 & 196 \\
Del 3AL-3 & 201 & 196 \\
Del 3AL-4 & 201 & 196 \\
Del 3AL-5 & 201 & 196 \\
Del 3AL-6 & 201 & 196 \\
Del 3AL-7 & 201 & 196 \\
Del 3AL-8 & &
\end{tabular}

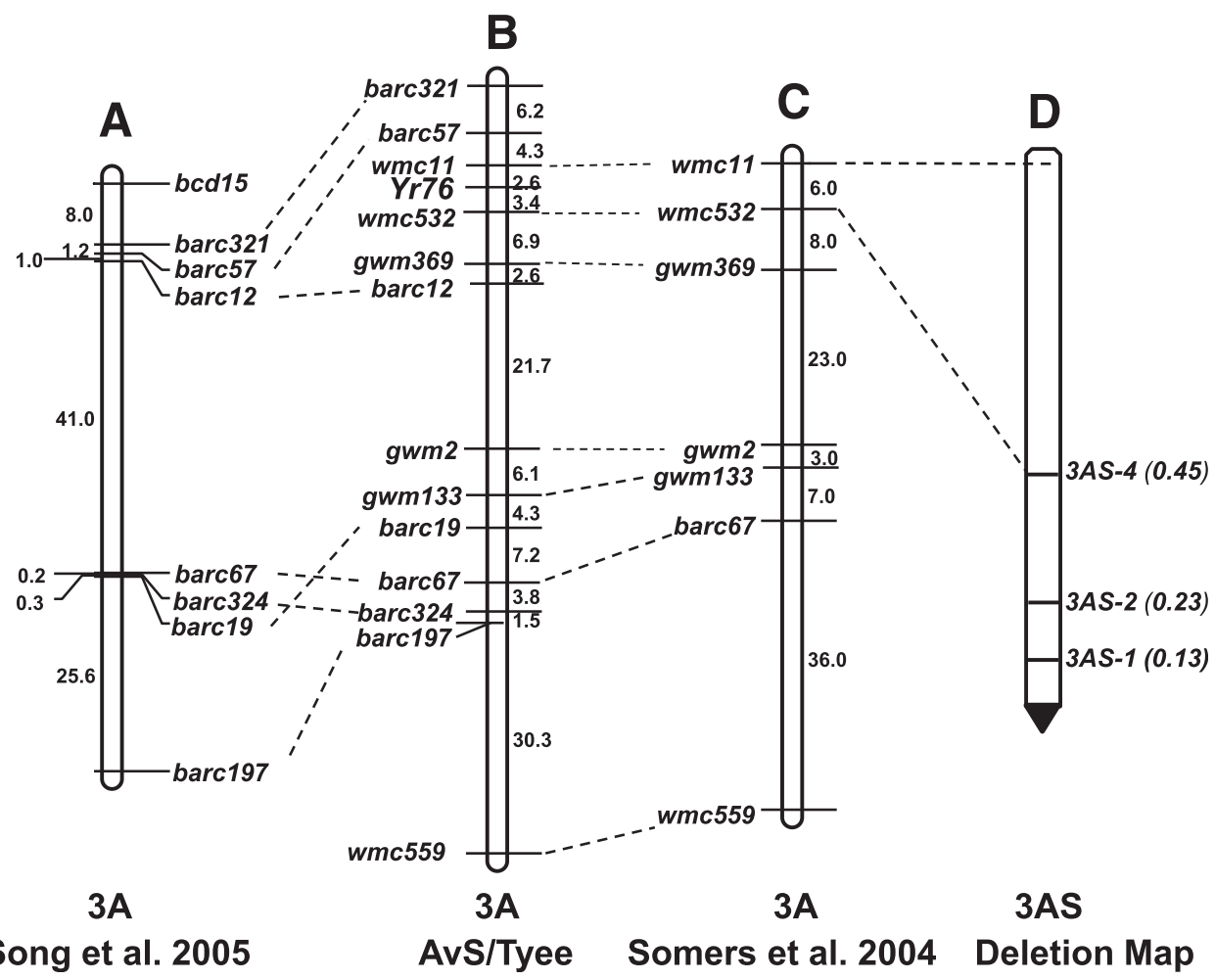

Fig. 2. Linkage map of Tyee/Avocet Susceptible (AvS) F population showing $\operatorname{Yr} 76$ (YrTye) on B, chromosome 3A and comparisons of the SSR markers in the consensus chromosome 3A maps of A, Song et al. (2005) and C, Somers et al. (2004) and D, Chinese Spring 3AS deletion map from the Kansas State University Wheat Genetics Resource Center (http://www.k-state.edu/wgrc/Germplasm/Deletions/grp3S.html). 
Bulk segregant analysis (Michelmore et al. 1991) was used in screening simple sequence repeat (SSR) markers. Based on the IT data for individual $\mathrm{F}_{2}$ plants and corresponding $\mathrm{F}_{2: 3}$ lines, a resistant bulk (RB) and a susceptible bulk (SB) were made with equal amounts of DNA sampled from 10 homozygous resistant (HR) and 10 homozygous susceptible (HS) $\mathrm{F}_{2}$ plants. The DNA samples from Tyee, AvS, and the two bulks were used in screening 650 markers covering all chromosomes.

PCR were performed in volumes of $12 \mu \mathrm{l}$ comprising $4 \mu \mathrm{l}$ (100 ng) of template DNA, $1.2 \mu \mathrm{l}$ of $10 \times$ buffer (with $1.5 \mathrm{mM} \mathrm{MgCl}_{2}$ ), $0.48 \mu \mathrm{l}$ of $\mathrm{MgCl}_{2}(25 \mathrm{mM}), 0.96 \mu \mathrm{l}$ of mixed dNTP with $2.5 \mathrm{mM}$ each, $0.24 \mu \mathrm{l}$ of M13 primer $(10 \mu \mathrm{M})$ with fluorescent dye, $0.12 \mu$ l of Taq DNA polymerase ( 5 unit/ $\mu \mathrm{l}), 0.06 \mu \mathrm{l}$ of forward primer with M13 tail $(10 \mu \mathrm{M})$, $0.3 \mu \mathrm{l}$ of reverse primer $(10 \mu \mathrm{M})$, and $4.64 \mu \mathrm{l}$ of sterilized $\mathrm{ddH}_{2} \mathrm{O}$. Buffer, dNTP, and Taq DNA polymerase were supplied by Promega Inc. (Madison, WI), and M13 fluorescent primers from Applied Biosystems (Grand Island, NY). SSR primers developed by Röder et al. (1998), Somers et al. (2004), and Song et al. (2005) were synthesized by Sigma-Aldrich Inc. (St. Louis, MO). PCR were performed in an ABI-9700 thermal cycler, programmed for $5 \mathrm{~min}$ of initial denaturation followed by 42 cycles, each cycle consisting of $1 \mathrm{~min}$ at $94^{\circ} \mathrm{C}, 1 \mathrm{~min}$ at 50 to $65^{\circ} \mathrm{C}$ annealing temperature depending on primers, and $1 \mathrm{~min}$ at $72^{\circ} \mathrm{C}$, followed by extension of $10 \mathrm{~min}$ at $72^{\circ} \mathrm{C}$. PCR products were detected on an ABI capillary DNA sequencer 3730 (Applied Biosystems, Foster City, CA), and the genotypes were analyzed using GeneMarker V2.2 (SoftGenetics, LLC, State College, PA).

Data analysis and molecular mapping. $\chi^{2}$ tests were used to evaluate the goodness of fit of observed segregations to expected inheritance ratios. A linkage map including the molecular markers and stripe rust response as a qualitative trait was constructed with software JoinMap 4.0 (Voorrips 2002). Markers were placed in a linkage group with a minimum LOD (logarithm of odds) threshold of 3.0, and the most likely order of linked markers was determined by three-point linkage analysis. Map distances in centiMorgans (cM) were calculated from recombination fraction using the Kosambi mapping function (Kosambi 1943). The genetic map was drawn using software Mapdraw V2.1 (Liu and Meng 2003).

Chromosomal location of YrTye. The chromosomal location of YrTye was determined by the locations of SSR markers linked to the gene based on the consensus maps of Somers et al. (2004), Song et al. (2005), and the wheat chromosome information available at the GrainGenes website (http://wheat.pw.usda.gov/GG3/maps-short). To confirm the chromosomal location and map YrTye to a chromosomal bin, Chinese Spring (CS), a complete set of 21 nulli-tetrasomic lines, and nine deletion lines of chromosome $3 \mathrm{~A}$ were tested with SSR markers flanking the YrTye locus based on the deletion maps of the Wheat Genetics Resource Center of Kansas State University (http://www.k-state.edu/wgrc/Germplasm/Deletions/grp3S.html).

Validation of markers flanking YrTye and determination of their polymorphisms in wheat genotypes. A total of 140 wheat genotypes were used to validate the markers and to determine marker polymorphisms in various wheat cultivars and breeding lines. These genotypes included club wheat and common wheat cultivars and breeding lines developed and/or grown in the U.S. Pacific Northwest. These genotypes, together with AvS and Tyee, were tested at the seedling stage under controlled conditions as described above with three $P$. striiformis f. sp. tritici races (PSTv-37, PSTV-40, and PSTv-79) avirulent to Tyee and three races (PSTv-4, PSTv-14, and PSTv-51) virulent to Tyee. The genotypes were also tested with two markers flanking the resistance gene locus.

\section{RESULTS}

Inheritance of stripe rust resistance in Tyee. When tested with the thirteen races at the seedling stage and diurnal temperature (4 to $20^{\circ} \mathrm{C}$ ) cycle, Tyee was resistant (IT 2) to PSTv-30, PSTv-34, PSTv-37, PSTv-40, PSTv-41, PSTv-55, PSTv-61, and PSTv-79, but susceptible (IT 8) to PSTv-4, PSTv-11, PSTv-14, PSTv-17, and
PSTv-51 (Table 1; Fig. 1). In contrast, AvS was susceptible (IT 8) to all of these races. Of the $135 \mathrm{~F}_{2}$ plants from cross AvS/Tyee tested with PSTV-37 at the seedling stage, 103 were resistant (IT 0 to 2 ) and 32 were susceptible (IT 8 to 9$)\left(\chi^{2} 3: 1=0.12, P_{1 \mathrm{df}}=0.73\right)$ with an absence of intermediate types, indicating a single dominant gene for resistance (Table 2). Of the $135 \mathrm{~F}_{2: 3}$ lines, 32 were homozygous susceptible and all derived from susceptible $\mathrm{F}_{2}$ plants; and 34 were homozygous resistant and 69 segregating, which were all from resistant $F_{2}$ plants. The segregation of $\mathrm{F}_{2: 3}$ lines fitted a $1 \mathrm{HR}: 2$ Seg: $1 \mathrm{HS}$ ratio $\left(\chi^{2}\right.$ 1:2:1 $=0.13$, $\left.P_{2 \mathrm{df}}=0.94\right)$. Tests of the $\mathrm{F}_{2: 3}$ lines with races PSTv-40 and PSTv-79 gave the same results. When $37 \mathrm{BC}_{1} \mathrm{~F}_{1}$ plants were tested with PSTV37,19 were resistant (IT 0 to 2 ) and 18 were susceptible (IT 7 to 9 ), fitting a 1:1 segregation ratio $\left(\chi^{2}{ }_{1: 1}=0.03, P_{1 \mathrm{df}}=0.97\right)$. These results indicated that Tyee has a dominant gene for resistance to stripe rust.

Molecular mapping of YrTye. Among 650 SSR markers covering all chromosomes initially screened, wmcll and barc321 on chromosome 3AS were polymorphic between the two parents and bulks (Supplementary Fig. S1). To further delimit the position of YrTye on chromosome 3A, additional 41 SSR markers on chromosome $3 \mathrm{~A}$ were screened, 11 were found polymorphic between the parents and bulks. Segregation at all 13 marker loci in the mapping populations fitted single gene ratios. A linkage map for chromosome $3 \mathrm{~A}$ based on the chromosomal location of the SSR markers compared with earlier maps (Somers et al. 2004; Song et al. 2005) is provided in Figure 2. The YrTye locus was flanked by wmc11 (2.6 cM distal) and wmc532 (3.4 cM proximal).

To determine physical location of YrTye, the two flanking markers were tested on CS and 21 nulli-tetrasomic lines representing all chromosomes and nine 3A deletion lines (Table 3). The CS alleles of the two markers were detected in all lines except N3AT3D-CS, Del 3AS-1, Del 3AS-2, and Del 3AS-4. Thus, YrTye was located in the distal bin 3AS4-0.45 to 1.00 (Fig. 2). Because no any formally named $\mathrm{Yr}$ genes was located on chromosome 3AS, we designated YrTye as Yr76.

Validation of flanking markers and their polymorphisms in various wheat genotypes. The reactions of 140 wheat genotypes to six P. striiformis f. sp. tritici races and amplicons at the wmcll and wmc532 loci, together with those of AvS and Tyee, are presented in Table 4. Twenty-nine lines were resistant to the three Tyee-avirulent races (PSTv-37, PSTv-40, and PSTv-79) and therefore possibly carried $Y r 76$. When tested with the flanking markers, five cultivars (ARS-Amber, ARS-Chrystal, Cara, Chukar, and Hyak), all with Tyee in their pedigrees, had the Tyee alleles of both markers, whereas 135 genotypes had either only one or neither Tyee allele.

Among the 135 wheat genotypes which do not have $Y r 76,14(10.37 \%)$ had the Tyee allele at the wmcll locus and $14(10.37 \%)$ had the Tyee allele at the $w m c 532$ locus, but none has the Tyee alleles at both the marker loci. The results indicate that when the two markers are used together, the presence or absence of $Y r 76$ can be accurately determined.

Development of a NIL for $Y \boldsymbol{r} 76$. A homozygous spring habit $\mathrm{F}_{3}$ line $\left(\mathrm{AvS} * 4 / \mathrm{TyeeF}_{3}-1\right)$ was selected from the AvS*4/Tyee cross based on stripe rust response and the presence of the flanking markers. The line closely resembles AvS morphology and responds to an array of $P$. striiformis f. sp. tritici races and can be used to replace Tyee in the differential set.

\section{DISCUSSION}

Due to its unique quality characteristics, club wheat is an important market class almost exclusively grown in the U.S. Pacific Northwest (Allan 2014). Prior to and when released in 1979, Tyee was highly resistant to stripe rust. So far, only a single gene, temporarily named YrTye, has been identified in Tyee with U.S. P. striiformis f. sp. tritici races (Chen and Line 1992a, 1992b; Chen et al. 1995). The resistance is believed to be derived from CItr 7805 (selection from PI 58787), a tetraploid introduction from Ethiopia (Allan 2014). This hypothesis can be accepted by the similar reactions to Tyee when tested with races avirulent or virulent to Tyee by early scientists in the USDA-ARS stripe rust program in 


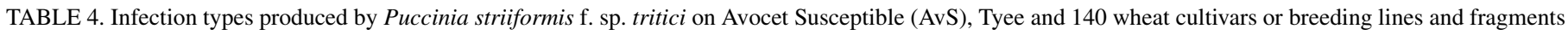
amplified by primers for simple sequence repeat (SSR) markers $w m c 11$ and $w m c 532$

\begin{tabular}{|c|c|c|c|c|c|c|c|c|c|c|}
\hline \multirow[b]{2}{*}{ Wheat } & \multirow[b]{2}{*}{ Growth habit or type ${ }^{a}$} & \multicolumn{6}{|c|}{ Infection type produced by $P$. striiformis $\mathrm{f}$. sp. tritici races } & \multicolumn{2}{|c|}{ Size of fragment (bp) } & \multirow[b]{2}{*}{ Yr76 } \\
\hline & & PSTv-4 & PSTv-14 & PSTv-37 & PSTv-40 & PSTv-51 & PSTV-79 & $w m c 11$ & $w m c 532$ & \\
\hline AvS & Spring & 8 & 8 & 8 & 8 & 8 & 8 & 200 & 178 & No \\
\hline Tyee & Club & 8 & 8 & 2 & 1 & 8 & 2 & 204 & 182 & Yes \\
\hline ARS-Chrystal & Club & 2 & 8 & 2 & 2 & 2 & 2 & 204 & 182 & Yes \\
\hline Cara & Club & 2 & 2 & 2 & 2 & 2 & 2 & 204 & 182 & Yes \\
\hline Chukar & Club & 2 & 2 & 2 & 2 & 2 & 2 & 204 & 182 & Yes \\
\hline Cabernet & Spring & 8 & 8 & 8 & 1 & 8 & 8 & 204 & 178 & No \\
\hline DH02-18-69 & Winter & 8 & 8 & 8 & 8 & 8 & 8 & 204 & 178 & No \\
\hline Eddy & Winter & 8 & 8 & 8 & 8 & 8 & 8 & 204 & 178 & No \\
\hline Expresso & Spring & 1 & 1 & 1 & 1 & 1 & 1 & 204 & 178 & No \\
\hline $\mathrm{JD}$ & $\mathrm{SC}$ & 2 & 8 & 2 & 8 & 2 & 1 & 204 & 178 & No \\
\hline Louise & Spring & 8 & 8 & 8 & 8 & 8 & 8 & 204 & 178 & No \\
\hline WB-Rockland & Spring & 1 & 1 & 1 & 1 & 1 & 1 & 204 & 178 & No \\
\hline Alum & Spring & 8 & 8 & 8 & 2 & 8 & 8 & 184 & 182 & No \\
\hline SY605 CL & Spring & 8 & 8 & 8 & 8 & 8 & 8 & 184 & 182 & No \\
\hline Zak & Spring & 8 & 8 & 8 & 8 & 8 & 8 & 184 & 182 & No \\
\hline Boundary & Winter & 8 & 8 & 8 & 8 & 8 & 8 & 184 & 182 & No \\
\hline IDO663 & Winter & 8 & 8 & 2 & 8 & 8 & 5 & 184 & 182 & No \\
\hline IDO816 & Winter & 2 & 2 & 5 & 8 & 8 & 2 & 184 & 182 & No \\
\hline Finley & Winter & 2 & 2 & 8 & 8 & 8 & 2 & 184 & 182 & No \\
\hline Ladd & Winter & 8 & 2 & 8 & 2 & 8 & 5 & 184 & 182 & No \\
\hline Kaseberg & Winter & 8 & 8 & 8 & 8 & 8 & 8 & 184 & 182 & No \\
\hline ORCF-103 & Winter & 8 & 8 & 8 & 8 & 8 & 8 & 184 & 182 & No \\
\hline UI Silver & Winter & 2 & 2 & 5 & 8 & 5 & 2 & 184 & 182 & No \\
\hline WA8153 & Winter & 8 & 8 & 8 & 8 & 8 & 8 & 184 & 182 & No \\
\hline WA8156 & Winter & 1 & 2 & 8 & 1 & 1 & 2 & 184 & 182 & No \\
\hline ARS-Crescent & Club & 2 & 8 & 8 & 8 & 5 & 1 & 184 & 178 & No \\
\hline Barbee & Club & 2 & 2 & 1 & 8 & 8 & 2 & 184 & 178 & No \\
\hline Bruehl & Club & 2 & 2 & 2 & 2 & 2 & 2 & 184 & 178 & No \\
\hline Coda & Club & 2 & 2 & 2 & 8 & 2 & 1 & 184 & 178 & No \\
\hline Crew & Club & 4 & 8 & 5 & 2 & 3 & 1 & 184 & 178 & No \\
\hline Hiller & Club & 2 & 8 & 5 & 5 & 4 & 1 & 184 & 178 & No \\
\hline Rely & Club & 2 & 8 & 1 & 5 & 2 & 1 & 184 & 178 & No \\
\hline Rohde & Club & 2 & 1 & 2 & 8 & 5 & 1 & 184 & 178 & No \\
\hline Alpowa & Spring & 8 & 8 & 8 & 8 & 8 & 8 & 184 & 178 & No \\
\hline Alturas & Spring & 8 & 8 & 8 & 8 & 8 & 8 & 184 & 178 & No \\
\hline ARS03173LS & Spring & 2 & 8 & 8 & 8 & 8 & 2 & 184 & 178 & No \\
\hline ARS03174CS & Spring & 8 & 8 & 8 & 8 & 8 & 1 & 184 & 178 & No \\
\hline BR7030 & Spring & 5 & 2 & 8 & 5 & 8 & 2 & 184 & 178 & No \\
\hline Bullseye & Spring & 8 & 8 & 8 & 2 & 8 & 8 & 184 & 178 & No \\
\hline Dayn & Spring & 5 & 5 & 5 & 2 & 5 & 2 & 184 & 178 & No \\
\hline Glee & Spring & 8 & 8 & 8 & 2 & 8 & 8 & 184 & 178 & No \\
\hline Hank & Spring & 8 & 8 & 8 & 2 & 8 & 1 & 184 & 178 & No \\
\hline Hollis & Spring & 2 & 8 & 8 & 2 & 8 & 2 & 184 & 178 & No \\
\hline IDO669 & Spring & 5 & 2 & 2 & 8 & 8 & 2 & 184 & 178 & No \\
\hline IDO671 & Spring & 8 & 8 & 8 & 8 & 8 & 8 & 184 & 178 & No \\
\hline IDO686 & Spring & 8 & 2 & 8 & 8 & 8 & 8 & 184 & 178 & No \\
\hline IDO687 & Spring & 8 & 8 & 8 & 8 & 8 & 8 & 184 & 178 & No \\
\hline IDO0694 & Spring & 8 & 8 & 8 & 8 & 8 & 2 & 184 & 178 & No \\
\hline Jedd & Spring & 8 & 2 & 2 & 2 & 5 & 2 & 184 & 178 & No \\
\hline Jefferson & Spring & 8 & 2 & 8 & 2 & 8 & 8 & 184 & 178 & No \\
\hline Kelse & Spring & 8 & 1 & 8 & 2 & 8 & 5 & 184 & 178 & No \\
\hline LCS-Powerplay & Spring & 8 & 8 & 8 & 8 & 8 & 8 & 184 & 178 & No \\
\hline
\end{tabular}

${ }^{a}$ For the purpose of this study, the wheat entries are listed as either spring or winter of common wheat, or club wheat; all club entries are winter habit except JD, which is a spring type (SC). 


\begin{tabular}{|c|c|c|c|c|c|c|c|c|c|c|}
\hline \multirow[b]{2}{*}{ Wheat } & \multirow[b]{2}{*}{ Growth habit or type ${ }^{a}$} & \multicolumn{6}{|c|}{ Infection type produced by $P$. striiformis f. sp. tritici races } & \multicolumn{2}{|c|}{ Size of fragment (bp) } & \multirow[b]{2}{*}{$Y r 76$} \\
\hline & & PSTv-4 & PSTv-14 & PSTv-37 & PSTV-40 & PSTv-51 & PSTv-79 & wmc11 & $w m c 532$ & \\
\hline Nick & Spring & 8 & 8 & 8 & 8 & 8 & 8 & 184 & 178 & No \\
\hline Scarlet & Spring & 8 & 8 & 8 & 8 & 8 & 5 & 184 & 178 & No \\
\hline Seahawk & Spring & 1 & 1 & 1 & 1 & 1 & 1 & 184 & 178 & No \\
\hline Tara 2002 & Spring & 8 & 8 & 8 & 2 & 8 & 8 & 184 & 178 & No \\
\hline UI-Stone & Spring & 8 & 8 & 8 & 8 & 8 & 8 & 184 & 178 & No \\
\hline UI-Winchester & Spring & 2 & 8 & 8 & 2 & 8 & 1 & 184 & 178 & No \\
\hline Volt & Spring & 8 & 2 & 2 & 2 & 2 & 2 & 184 & 178 & No \\
\hline WA8124 & Spring & 2 & 2 & 8 & 8 & 5 & 2 & 184 & 178 & No \\
\hline WA8160 & Spring & 2 & 2 & 8 & 8 & 8 & 2 & 184 & 178 & No \\
\hline WA8161 & Spring & 2 & 2 & 2 & 2 & 2 & 2 & 184 & 178 & No \\
\hline WA8165 & Spring & 8 & 8 & 8 & 2 & 8 & 2 & 184 & 178 & No \\
\hline WA8167 & Spring & 1 & 2 & 1 & 2 & 2 & 1 & 184 & 178 & No \\
\hline WA8168 & Spring & 8 & 8 & 8 & 8 & 8 & 2 & 184 & 178 & No \\
\hline Wakanz & Spring & 8 & 8 & 8 & 2 & 5 & 8 & 184 & 178 & No \\
\hline WB-Fuzion & Spring & 8 & 8 & 8 & 8 & 8 & 8 & 184 & 176 & No \\
\hline WB Hartline & Spring & 8 & 8 & 8 & 2 & 8 & 2 & 184 & 178 & No \\
\hline Whit & Spring & 8 & 8 & 8 & 8 & 8 & 8 & 184 & 178 & No \\
\hline ARS-Selbu & Winter & 2 & 8 & 2 & 2 & 2 & 1 & 184 & 178 & No \\
\hline Azimut & Winter & 3 & 2 & 5 & 8 & 2 & 2 & 184 & 178 & No \\
\hline Bauermeister & Winter & 8 & 8 & 8 & 8 & 8 & 8 & 184 & 178 & No \\
\hline Curiosity CL+ & Winter & 2 & 2 & 5 & 5 & 2 & 2 & 184 & 178 & No \\
\hline Eltan & Winter & 8 & 8 & 8 & 8 & 8 & 8 & 184 & 178 & No \\
\hline Genesi & Winter & 8 & 8 & 8 & 8 & 8 & 2 & 184 & 178 & No \\
\hline LWW-04-4009 & Winter & 5 & 8 & 8 & 8 & 5 & 5 & 184 & 178 & No \\
\hline MDM & Winter & 2 & 8 & 8 & 8 & 8 & 8 & 184 & 178 & No \\
\hline Mela CL+ & Winter & 2 & 8 & 8 & 8 & 8 & 2 & 184 & 178 & No \\
\hline OR08047P94 & Winter & 3 & 2 & 1 & 3 & 4 & 3 & 184 & 178 & No \\
\hline OR2080229H & Winter & 8 & 5 & 2 & 8 & 5 & 8 & 184 & 178 & No \\
\hline OR2080236H & Winter & 8 & 1 & 1 & 1 & 8 & 2 & 184 & 178 & No \\
\hline OR2701071 & Winter & 7 & 8 & 2 & 5 & 5 & 5 & 184 & 178 & No \\
\hline Raeder & Winter & 2 & 2 & 1 & 8 & 5 & 3 & 184 & 198 & No \\
\hline Rod & Winter & 8 & 2 & 3 & 5 & 8 & 8 & 184 & 178 & No \\
\hline Stephens & Winter & 8 & 8 & 8 & 8 & 8 & 8 & 184 & 178 & No \\
\hline UICF-Grace & Winter & 8 & 8 & 2 & 8 & 8 & 8 & 184 & 178 & No \\
\hline WA8092 & Winter & 3 & 8 & 2 & 8 & 2 & 2 & 184 & 178 & No \\
\hline WA8116 & Winter & 2 & 8 & 1 & 2 & 5 & 3 & 184 & 178 & No \\
\hline WA8136 & Winter & 5 & 8 & 5 & 8 & 2 & 2 & 184 & 178 & No \\
\hline WA8137 & Winter & 8 & 8 & 8 & 8 & 8 & 8 & 184 & 178 & No \\
\hline WA8151 & Winter & 8 & 8 & 5 & 8 & 8 & 5 & 184 & 178 & No \\
\hline WA8152 & Winter & 8 & 8 & 8 & 8 & 8 & 8 & 184 & 178 & No \\
\hline Xerpha & Winter & 8 & 8 & 8 & 8 & 8 & 8 & 184 & 178 & No \\
\hline UI SRG & Winter & 2 & 2 & 2 & 8 & 8 & 1 & 188 & 178 & No \\
\hline CW 515 & Spring & 2 & 1 & 2 & 2 & 2 & 2 & 200 & 178 & No \\
\hline Patwin 515 & Spring & 1 & 2 & 2 & 1 & 1 & 1 & 200 & 178 & No \\
\hline V272 & Spring & 2 & 8 & 8 & 8 & 8 & 2 & 200 & 178 & No \\
\hline Altigo & Winter & 8 & 8 & 5 & 8 & 5 & 2 & 200 & 178 & No \\
\hline DH02-18-88 & Winter & 8 & 8 & 8 & 8 & 8 & 8 & 200 & 178 & No \\
\hline Madsen & Winter & 8 & 2 & 2 & 2 & 8 & 2 & 200 & 178 & No \\
\hline Masami & Winter & 8 & 8 & 8 & 8 & 8 & 8 & 200 & 178 & No \\
\hline Norwest 553 & Winter & 5 & 8 & 8 & 8 & 8 & 8 & 200 & 178 & No \\
\hline OR2080 $156 \mathrm{H}$ & Winter & 8 & 8 & 5 & 2 & 5 & 5 & 200 & 178 & No \\
\hline ORCF-102 & Winter & 8 & 8 & 8 & 8 & 8 & 8 & 200 & 178 & No \\
\hline Skiles & Winter & 8 & 8 & 8 & 8 & 8 & 8 & 200 & 178 & No \\
\hline Tubbs 06 & Winter & 8 & 8 & 8 & 5 & 8 & 8 & 200 & 178 & No \\
\hline WA8061-10 & Winter & 2 & 5 & 8 & 8 & 5 & 2 & 200 & 178 & No \\
\hline WA 8115 & Winter & 8 & 8 & 8 & 8 & 8 & 2 & 200 & 178 & No \\
\hline WA8134 & Winter & 8 & 2 & 8 & 2 & 8 & 4 & 200 & 178 & No \\
\hline WA8135 & Winter & 8 & 8 & 8 & 8 & 8 & 5 & 200 & 178 & No \\
\hline WA8142 & Winter & 7 & 8 & 5 & 5 & 2 & 2 & 200 & 178 & No \\
\hline WA8157 & Winter & 5 & 8 & 2 & 8 & 8 & 2 & 200 & 178 & No \\
\hline WA8158 & Winter & 2 & 2 & 2 & 5 & 2 & 2 & 200 & 178 & No \\
\hline WA8159 & Winter & 5 & 8 & 2 & 8 & 5 & 2 & 200 & 178 & No \\
\hline WB-528 & Winter & 8 & 8 & 8 & 8 & 8 & 8 & 200 & 178 & No \\
\hline Babe & Spring & 8 & 8 & 8 & 8 & 8 & 8 & 202 & 178 & No \\
\hline Diva & Spring & 5 & 8 & 8 & 5 & 8 & 8 & 202 & 178 & No \\
\hline WA8131 & Spring & 2 & 2 & 2 & 2 & 2 & 2 & 202 & 178 & No \\
\hline Esperia & Winter & 8 & 8 & 8 & 8 & 8 & 8 & 202 & 178 & No \\
\hline Farnum & Winter & 2 & 8 & 8 & 8 & 8 & 3 & 202 & 178 & No \\
\hline Sprinter & Winter & 2 & 8 & 2 & 2 & 2 & 2 & 202 & 178 & No \\
\hline WA8139 & Winter & 8 & 8 & 8 & 8 & 8 & 5 & 202 & 178 & No \\
\hline NSA06-2153A & Winter & 5 & 8 & 5 & 8 & 5 & 2 & 202 & 196 & No \\
\hline WA8154 & Winter & 8 & 8 & 8 & 2 & 8 & 2 & 202 & 178 & No \\
\hline Percent $(\%)$ pol & orphism for marker locu & & & & & & & 89.6 & 89.6 & \\
\hline Percent (\%) pol & orphism for both marker & & & & & & & 100.0 & & \\
\hline
\end{tabular}


1984 (https://npgsweb.ars-grin.gov/gringlobal/accessiondetail.aspx? $\mathrm{id}=1041287$ ). Tyee was one of the major winter club wheat cultivars grown in the U.S. Pacific Northwest in the 1980s, and its derivative cultivars have been continually used for developing wheat cultivars especially club wheat. Based on the results of the present study, YrTye is present only in winter club wheats, except ARS-Amber (PI 665047), a soft white common winter wheat cultivar (https:// npgsweb.ars-grin.gov/gringlobal/accessiondetail.aspx?id=1901441) also developed in the USDA-ARS club wheat breeding program (K. Garland-Campbell, unpublished data). The resistance gene from Tyee is still useful when combined with other major or minor rust resistance genes. In fact, the high level and broad-spectrum resistance in several recently released club wheat cultivars, such as Chukar, Cara, and ARS-Crystal, and common wheat ARS-Amber shown in the present study, were achieved by combining the Tyee gene with other all-stage resistance genes and/or high-temperature adult-plant (HTAP) resistance genes (Garland-Campbell et al. 2005, 2013).

We confirmed that Tyee has a single gene for resistance to the majority of $P$. striiformis $\mathrm{f}$. sp. tritici races. We constructed a genetic map with 13 SSR markers covering $100.9 \mathrm{cM}$, with the closest flanking markers being 2.6 proximal and $3.4 \mathrm{cM}$ distal to YrTye. Using CS 3A deletion lines, we located the gene in bin 3AS4-0.5 to 1.00. This study corrected the previous report suggesting the gene on chromosome 6D (Chen et al. 1995).

Only four temporarily named stripe rust resistance genes or quantitative trait loci (QTL) have been reported on chromosome 3A. $\operatorname{YrTr} 2$ was located to chromosome $3 \mathrm{~A}$ in club wheat cultivar Tres along with a second gene $(Y r \operatorname{Tr} 1)$ for all-stage resistance. $Y r T r 2$ alone provides resistance to only few races, and its chromosomal location is unknown (Chen et al. 1995). Because $\operatorname{YrTrl}$ confers resistance to more races than $Y r T r 2$ and an NIL line in the AvS background has been developed for this gene (Wellings et al. 2004), the $\operatorname{YrTr} 1$ NIL is included in the current set of $Y r$ single-gene line differentials (Wan and Chen 2014). YrTye and YrTrl display different race specificities (Wan and Chen 2014). Thus, Yr76 (YrTye) is different from either $Y r \operatorname{Tr} 1$ or $Y r T r 2$. Lillemo et al. (2008) identified an unnamed QTL associated with adult-plant resistance to stripe rust on chromosome 3AS and linked to SSR marker Xbarc310 in wheat cultivar Saar. Based on the map for this QTL, it is located 11.1 and $14.4 \mathrm{cM}$ from Xwmc11 and Xwmc532, respectively. Because of different types of resistance, YrTye should be different from this QTL. Yrq2 was mapped on chromosome 3AS in wheat line Xichang 76-9 but confers slow rusting (Cao et al. 2012), and therefore should be different from YrTye. Through genome-wide association mapping, Jighly et al. (2015) reported a QTL on 3AS to confer seedling resistance, but neither the gene nor its location has been validated. Because of no any formally named $Y r$ gene was previously located on chromosome 3AS (McIntosh et al. 2014), we named YrTye as Yr76.

Marker-assisted selection is a powerful tool for pyramiding genes of important traits, including multiple genes for resistance to a single disease (Mallick et al. 2015; Yaniv et al. 2015). The value of any marker for breeding depends upon the closeness of linkage of a marker and gene of interest and on the uniqueness of the association between marker allele and gene source. In the present study, we identified flanking SSR markers, wmc11 and wmc532, to Yr76; and these markers were highly polymorphic among different wheat varieties used in validation. Thus, the markers can be used to incorporate $\mathrm{Yr} 76$ into various wheat backgrounds. As $Y r 76$ is race-specific, it should not be used alone. Therefore, combinations of this gene with other widely effective all-stage resistance genes such as $\operatorname{Yr} 5, \operatorname{Yr} 15, \mathrm{Yr} 45, \mathrm{Yr} 53$, Yr61, Yr64, Yr65, and YrSP (Chen et al. 2003; Cheng et al. 2014; Feng et al. 2015; Li et al. 2010; Murphy et al. 2009; Xu et al. 2013; Zhou et al. 2014a), and/or with genes for HTAP resistance such as Yr36, Yr39, Yr52, Yr59, Yr62, and many temporarily named QTL (Carter et al. 2009; Chen 2013; Lin and Chen 2007, 2009; Lu et al. 2014; Ren et al. 2012; Uauy et al. 2005; Zhou et al. 2014b) are recommended.

Tyee is an excellent differential for identifying $P$. striiformis f. sp. tritici races as it provides very clear low and high responses with low probability of misclassification (Sharma-Poudyal et al. 2013; Wan and Chen 2014; Wan et al. 2016; Zhan et al. 2012). Race groups separated by virulence and avirulence on Tyee correspond to genetic groups separated by molecular markers (Cheng and Chen 2014; A. M. Wan and X. M. Chen, unpublished data). Because Tyee is the only winter wheat used in the current $Y r$ single-gene differentials (Wan and Chen 2014), it often cannot be compared with other differential lines in the field for monitoring $P$. striiformis f. sp. tritici virulence. We developed a nearisogenic line of spring common wheat $\left(\mathrm{AvS}^{*} 4 / \mathrm{TyeeF}_{3}-1\right)$ carrying $\operatorname{Yr} 76$. Our preliminary result of this line is equal to Tyee in differentiating races. This spring wheat line with $Y r 76$ can be added to the AvS series and can be more easily used in stripe rust research worldwide.

\section{ACKNOWLEDGMENTS}

This research was supported by the U.S. Department of Agriculture, Agricultural Research Service (Project 5348-22000-015-00D) and Washington State University (Project 13C-3061-5665 and 13Z-3061-6665) PPNS 0710, Department of Plant Pathology, College of Agricultural, Human, and Natural Resource Sciences, Agricultural Research Center, HATCH Project WNP00663, Washington State University, Pullman 99164-6430. The China Scholarship Council scholarships to C. Xiang and J. Feng are highly appreciated. We thank R. McIntosh and K. Garland-Campbell for critical review of the manuscript and R. McIntosh for approving the gene symbol. Mention of trade names or commercial products in this publication is solely for the purpose of providing specific information and does not imply recommendation or endorsement by the U.S. Department of Agriculture. USDA is an equal opportunity provider and employer.

\section{LITERATURE CITED}

Allan, R., Peterson, C., Line, R., George, D., and Rubenthaler, G. 1980. Registration of Tyee wheat (Reg. No. 640). Crop Sci. 20:829-830.

Allan, R. E. 2014. Club wheat. Copyright 2014 Robert E. Allan, All rights reserved. ISBN 978-1-4951-0549-4.

Cao, X., Zhou, J., Gong, X., Zhao, G., Jia, J., and Qi, X. 2012. Identification and validation of a major quantitative trait locus for slow-rusting resistance to stripe rust in wheat. J. Integr. Plant Biol. 54:330-344.

Carter, A. H., Chen, X. M., Garland-Campbell, K., and Kidwell, K. K. 2009. Identifying QTL for high-temperature adult-plant resistance to stripe rust (Puccinia striiformis f. sp. tritici) in the spring wheat (Triticum aestivum L.) cultivar 'Louise'. Theor. Appl. Genet. 119:1119-1128.

Chen, W. Q., Wellings, C., Chen, X. M., Kang, Z. S., and Liu, T. G. 2014. Wheat stripe (yellow) rust caused by Puccinia striiformis f. sp. tritici. Mol. Plant Pathol. 15:433-446.

Chen, X. M. 2005. Epidemiology and control of stripe rust [Puccinia striiformis f. sp. tritici] on wheat. Can. J. Plant Pathol. 27:314-337.

Chen, X. M. 2013. Review article: High-temperature adult-plant resistance, key for sustainable control of stripe rust. Am. J. Plant Sci. 4:608-627.

Chen, X. M. 2014. Integration of cultivar resistance and fungicide application for control of wheat stripe rust. Can. J. Plant Pathol. 36:311-326.

Chen, X. M., and Line, R. F. 1992a. Identification of stripe rust resistance genes in wheat genotypes used to differentiate North American races of Puccinia striiformis. Phytopathology 82:1428-1434.

Chen, X. M., and Line, R. F. 1992b. Inheritance of stripe rust resistance in wheat cultivars used to differentiate races of Puccinia striiformis in North America. Phytopathology 82:633-637.

Chen, X. M., and Line, R. F. 1995. Gene-action in wheat cultivars for durable, high-temperature, adult-plant resistance and interaction with race-specific, seedling resistance to Puccinia striiformis. Phytopathology 85:567-572.

Chen, X. M., Line, R. F., and Jones, S. S. 1995. Chromosomal location of genes for resistance to Puccinia striiformis in winter wheat cultivars Heines VII, Clement, Moro, Tyee, Tres, and Daws. Phytopathology 85:1362-1367.

Chen, X. M., Moore, M., Milus, E. A., Long, D. L., Line, R. F., Marshall, D., and Jackson, L. 2002. Wheat stripe rust epidemics and races of Puccinia striiformis f. sp. tritici in the United States in 2000. Plant Dis. 86:39-46.

Chen, X. M., Penman, L., Wan, A. M., and Cheng, P. 2010. Virulence races of Puccinia striiformis f. sp. tritici in 2006 and 2007 and development of wheat stripe rust and distributions, dynamics, and evolutionary relationships of races from 2000 to 2007 in the United States. Can. J. Plant Pathol. 32:315-333.

Chen, X. M., Soria, M. A., Yan, G. P., Sun, J., and Dubcovsky, J. 2003. Development of sequence tagged site and cleaved amplified polymorphic sequence markers for wheat stripe rust resistance gene Yr5. Crop Sci. 43:2058-2064. 
Cheng, P., and Chen, X. M. 2014. Virulence and molecular analyses support asexual reproduction of Puccinia striiformis f. sp. tritici in the U.S. Pacific Northwest. Phytopathology 104:1208-1220.

Cheng, P., Xu, L. S., Wang, M. N., See, D. R., and Chen, X. M. 2014. Molecular mapping of genes $\operatorname{Yr} 64$ and $\operatorname{Yr} 65$ for stripe rust resistance in hexaploid derivatives of durum wheat accessions PI 331260 and PI 480016. Theor. Appl. Genet. 127:2267-2277.

Feng, J. Y., Wang, M. N., Chen, X. M., See, D. R., Zheng, Y. L., Chao, S. M., and Wan, A. M. 2015. Molecular mapping of $\operatorname{YrSP}$ and its relationship with other genes for stripe rust resistance in wheat chromosome 2BL. Phytopathology 105:1206-1213.

Garland-Campbell, K., Allan, R. E., Anderson, J., Little, L. M., Pritchett, J., Blake, N., Burke, A., Hoagland, C., Walker, C., Chen, X. M., Morris, C., Guy, S., Murray, T., See, D., Engle, D., Wetzel, H., and Wood, D. 2013. Registration of 'Cara' soft white winter club wheat. J. Plant Reg. 7:81-88.

Garland-Campbell, K., Allan, R. E., Anderson, J., Pritchett, J., Little, L. M., Morris, C. F., Line, R. F., Chen, X. M., Walker-Simmons, M. K., Carter, B. P., Burns, J. W., Jones, S. S., and Reisenauer, P. E. 2005. Registration of 'Chukar' winter club wheat. Crop Sci. 45:1657-1658.

Jighly, A., Oyiga, B. C., Makdis, F., Nazari, K., Youssef, O., Tadesse, W., Abdalla, O., and Ogbonnaya, F. C. 2015. Genome-wide DArT and SNP scan for QTL associated with resistance to stripe rust (Puccinia striiformis $\mathrm{f}$. $\mathrm{sp}$. tritici) in elite ICARDA wheat (Triticum aestivum L.) germplasm. Theor. Appl. Genet. 128:1277-1295.

Johnson, R. 1981. Durable resistance: Definition of, genetic control, and attainment in plant breeding. Phytopathology 71:567-568.

Kosambi, D. D. 1943. The estimation of map distances from recombination values. Ann. Eugen. 12:172-175.

Li, Q., Chen, X. M., Wang, M. N., and Jing, J. X. 2010. Yr45, a new wheat gene for stripe rust resistance mapped on the long arm of chromosome 3D. Theor. Appl. Genet. 122:189-197.

Lillemo, M., Asalf, B., Singh, R., Huerta-Espino, J., Chen, X., He, Z., and Bjørnstad, А. 2008. The adult plant rust resistance loci $L r 34 / Y r 18$ and $L r 46 /$ Yr29 are important determinants of partial resistance to powdery mildew in bread wheat line Saar. Theor. Appl. Genet. 116:1155-1166.

Lin, F., and Chen, X. M. 2007. Genetics and molecular mapping of genes for race-specific all-stage resistance and non-race specific high-temperature adult-plant resistance to stripe rust in spring wheat cultivar Alpowa. Theor. Appl. Genet. 114:1277-1287.

Lin, F., and Chen, X. M. 2009. Quantitative trait loci for non-race-specific, high-temperature adult-plant resistance to stripe rust in wheat cultivar Express. Theor. Appl. Genet. 118:631-642.

Line, R. F., and Chen, X. M. 1995. Successes in breeding for and managing durable resistance to wheat rusts. Plant Dis. 79:1254-1255.

Line, R. F., and Qayoum, A. 1992. Virulence, aggressiveness, evolution, and distribution of races of Puccinia striiformis (the cause of stripe rust of wheat) in North America 1968-87. U.S. Dep. Agric.-Agric. Res. Serv. Tech. Bull. No. 1788.

Liu, R., and Meng, J. 2003. MapDraw: A Microsoft Excel macro for drawing genetic linkage maps based on given genetic linkage data. Hereditas 25:317-321.

Lu, Y., Wang, M. N., Chen, X. M., See, D. R., Chao, S. M., and Jing, J. X. 2014. Mapping of Yr62 and a small effect QTL for high-temperature adultplant resistance to stripe rust in spring wheat PI 192252. Theor. Appl. Genet. 127:1449-1459.

Mallick, N., Vinod, J. B., Sharma, R. S., Tomar, M. S., and Prabhu, K. V. 2015. Marker-assisted backcross breeding to combine multiple rust resistance in wheat. Plant Breed. 134:172-177.

McIntosh, R., Dubcovsky, J., Rogers, W., Morris, C., Appels, R., and Xia, X. 2014. Catalogue of gene symbols for wheat: 2013-2014 supplement. http:// shigen.nig.ac.jp/wheat/komugi/genes/macgene/supplement2013.pdf

Michelmore, R. W., Paran, I., and Kesseli, R. 1991. Identification of markers linked to disease-resistance genes by bulked segregant analysis: A rapid method to detect markers in specific genomic regions by using segregating populations. Proc. Nat. Acad. Sci. 88:9828-9832.

Murphy, L. R., Santra, D., Kidwell, K., Yan, G. P., Chen, X. M., and Campbell, K. G. 2009. Linkage maps of wheat stripe rust resistance genes $\operatorname{Yr} 5$ and Yr15 for use in marker assisted selection. Crop Sci. 49:1786-1790.

Ren, R. S., Wang, M. N., Chen, X. M., and Zhang, Z. J. 2012. Characterization and molecular mapping of Yr52 for high-temperature adult-plant resistance to stripe rust in spring wheat germplasm PI 183527. Theor. Appl. Genet. 125:847-857.

Riede, C., and Anderson, J. 1996. Linkage of RFLP markers to an aluminum tolerance gene in wheat. Crop Sci. 36:905-909.

Röder, M. S., Korzun, V., Wendehake, K., Plaschke, J., Tixier, M.-H., Leroy, P., and Ganal, M. W. 1998. A microsatellite map of wheat. Genetics 149: 2007-2023.

Sharma-Poudyal, D., and Chen, X. M. 2011. Models for predicting potential yield loss of wheat caused by stripe rust in the U.S. Pacific Northwest. Phytopathology 101:544-554.

Sharma-Poudyal, D., Chen, X. M., Wan, A. M., Zhan, G. M., Kang, Z. S., Cao, S. Q., Jin, S. L., Morgounov, A., Akin, B., Mert, Z., Shah, S. J. A., Bux, H., Ashraf, M., Sharma, R. C., Madariaga, R., Puri, K. D., Wellings, C., Xi, K. Q., Wanyera, R., Manninger, K., Ganzalez, M. I., Koyda, M., Sanin, S., and Patzek, L. J. 2013. Virulence characterization of international collections of the wheat stripe rust pathogen, Puccinia striiformis f. sp. tritici. Plant Dis. 97:379-386.

Somers, D. J., Isaac, P., and Edwards, K. 2004. A high-density microsatellite consensus map for bread wheat (Triticum aestivum L.). Theor. Appl. Genet. 109:1105-1114

Song, Q., Shi, J., Singh, S., Fickus, E., Costa, J., Lewis, J., Gill, B., Ward, R., and Cregan, P. 2005. Development and mapping of microsatellite (SSR) markers in wheat. Theor. Appl. Genet. 110:550-560.

Stubbs, R. W. 1985. Stripe rust. Pages 61-101 in: The Cereal Rusts, Vol. II, Disease, Distribution, Epidemiology and Control. A. P. Roelfs and W. R. Bushnell, eds. Academic Press, Orlando, FL

Uauy, C., Brevis, J. C., Chen, X. M., Khan, I. A., Jackson, L. F., Chicaiza, O., Distelfeld, A., Fahima, T., and Dubcovsky, J. 2005. High-temperature adult plant (HTAP) stripe rust resistance gene Yr36 from Triticum turgidum ssp. dicoccoides is closely linked to the grain protein content locus $G p c-B 1$. Theor. Appl. Genet. 112:97-105.

Voorrips, R. 2002. MapChart: Software for the graphical presentation of linkage maps and QTLs. J. Hered. 93:77-78.

Wan, A. M., and Chen, X. M. 2012. Virulence, frequency, and distribution of races of Puccinia striiformis f. sp. tritici and P. striiformis f. sp. hordei identified in the United States in 2008 and 2009. Plant Dis. 96:67-74.

Wan, A. M., and Chen, X. M. 2014. Virulence characterization of Puccinia striiformis $\mathrm{f}$. sp. tritici using a new set of $Y r$ single-gene line differentials in the United States in 2010. Plant Dis. 98:1534-1542.

Wan, A. M., and Chen, X. M., and Yuen, J. 2016. Races of Puccinia striiformis f. sp. tritici in the United States in 2011 and 2012 and comparison with races in 2010. Plant Dis. 100:966-975.

Wellings, C. R. 2011. Global status of stripe rust: a review of historical and current threats. Euphytica 179:129-141.

Wellings, C. R., Singh, R. P., McIntosh, R. A., and Pretorius, Z. A. 2004. The development and application of near isogenic lines for the stripe (yellow) rust pathosystem. Page A1.39 in: Abstracts of Proc. 11th Int. Cereal Rusts and Powdery Mildew Conf., Norwich, England.

Xu, L. S., Wang, M. N., Cheng, P., Kang, Z. S., Hulbert, S. H., and Chen, X. M. 2013. Molecular mapping of Yr53, a new gene for stripe rust resistance in durum wheat accession PI 480148 and its transfer to common wheat. Theor. Appl. Genet. 126:523-533.

Yaniv, E., Raats, D., Ronin, Y., Korol, A. B., Grama, A., Bariana, H. S., Dubcovsky, J., Schulman, A. H., and Fahima, T. 2015. Evaluation of marker-assisted selection for the stripe rust resistance gene $Y r 15$, introgressed from wild emmer wheat. Mol. Breed. 35:43.

Zhan, G. M., Chen, X. M., Kang, Z. S., Huang, L. L., Wang, M. N., Wan, A. M., Cheng, P., Cao, S. Q., and Jin, S. L. 2012. Virulence and molecular comparison of Puccinia striiformis $\mathrm{f}$. sp. tritici populations in China and the United States. Fungal Biol. 116:643-653.

Zhou, X. L., Han, D. J., Chen, X. M., Gou, H. L., Guo, S. J., Rong, L., Wang, Q. L., Huang, L. L., and Kang, Z. S. 2014a. Characterization and molecular mapping of stripe rust resistance gene $\mathrm{Yr} 61$ in winter wheat cultivar Pindong 34. Theor. Appl. Genet. 127:2349-2358.

Zhou, X. L., Wang, M. N., Chen, X. M., Lu, Y., Kang, Z. S., and Jing, J. X. 2014b. Identification of Yr59 conferring high-temperature adult-plant resistance to stripe rust in wheat germplasm PI 178759. Theor. Appl. Genet. 127:935-945. 